\title{
JOVENS EVANGÉLICOS E REPRESENTAÇÕES POLÍTICO-RELIGIOSAS NA CAMPANHA ELEITORAL DE 2012 EM CAMPO MOURÃO, PARANÁ
}

\author{
Frank Antonio Mezzomo ${ }^{1}$ \\ Cristina Satiê de Oliveira Pátaro ${ }^{2}$ \\ Thais Serafim ${ }^{3}$ \\ Andressa Paula ${ }^{4}$
}

Resumo: No presente artigo, busca-se analisar as representações de jovens evangélicos quanto às esferas da religião e da política, problematizando as dinâmicas que envolvem as articulações entre os dois campos. Foram entrevistados vinte e quatro jovens evangélicos vinculados à Igreja Assembleia de Deus, Igreja Presbiteriana Renovada, Igreja do Evangelho Quadrangular e Igreja Universal do Reino de Deus, por ocasião das eleições proporcionais ocorridas em 2012 no município de Campo Mourão, Paraná. Os resultados indicam que, para os jovens, a religião apresenta-se como um caminho para a relação com Deus, enquanto a política é encarada com certo ceticismo, tendo em vista a imoralidade, a corrupção e a defesa de interesses corporativistas que marcam o cenário atual. As relaçôes entre política e religião são encaradas por uns como uma chance de salvação para a política contemporânea, e por outros como dois campos distantes demais para se articularem.

1 Professor do Programa de Pós-Graduação Interdisciplinar Sociedade e Desenvolvimento da Universidade Estadual do Paraná (PPGSeD/Unespar). Campus de Campo Mourão, Brasil. Contato: frankmezzomo@gmail.com

2 Professora do Programa de Pós-Graduação Interdisciplinar Sociedade e Desenvolvimento da Universidade Estadual do Paraná (PPGSeD/Unespar). Campus de Campo Mourão, Brasil. Contato: crispataro@gmail.com

3 Mestranda e bolsista da Fundação Araucária/CAPES do Programa de Pós-Graduação Interdisciplinar Sociedade e Desenvolvimento da Universidade Estadual do Paraná (PPGSeD /Unespar). Campus de Campo Mourão, Brasil. Contato: serafim_thais@hotmail.com

${ }^{4}$ Bolsista de Iniciação Científica do CNPq. Universidade Estadual do Paraná (Unespar). Campus de Campo Mourão, Brasil. Contato: dessapaula_250@hotmail.com

Debates do NER, Porto Alegre, Ano i6, N. 27, P. 233-258, JAn./Jun. 2015 
Palavras-chave: Jovens; Política; Religião.

\begin{abstract}
In this article, we intend to analyze the representations of evangelicals youths towards the spheres of religion and politics, discussing the dynamics surrounding the links between the two fields. Interviews were conducted with twenty-four evangelicals youths linked to Assembly of God Church, Renewal Presbyterian Church, Foursquare Church and Universal Church of the Kingdom of God, on the occasion of the 2012 Campo Mourão, Paraná, Brazil proportional elections. The results indicate that for young people, religion is presented as a path to a relationship with God, while the politics is viewed with skepticism, given the immorality, corruption and the defense of corporatist interests that mark the current scenario. The relationship between politics and religion is seen by some as a chance of salvation for contemporary politics, and to other as very distant fields to articulate with each other.
\end{abstract}

Keywords: Youth; Politics; Religion.

\title{
INTRODUÇÃO
}

A compreensão das relaçóes entre religião e política tem requerido a problematização de alguns dos pilares da modernidade, especificamente no que tange às ideias secularizantes que apregoavam o arrefecimento da religião e a proeminência da racionalidade na organização e nas relações sociais. Afinal, a despeito do que a teoria clássica vaticinou acerca do lugar da religião na sociedade contemporânea, entendemos que "[...] a dimensão religiosa tem resistido a se circunscrever à vida privada, ao foro íntimo, e hoje ganha outros fôlegos não previstos na grande narrativa que separou religião e política, o público e o privado, magia e religião" (Novaes, 2012, p. 184). Assim, quer no plano da cultura e do cotidiano, quer no da esfera pública e da política, os sujeitos movimentam-se e trazem à tona a linguagem, as representaçōes, o ethos religioso. Há, desse modo, diálogos múltiplos entre secularização e manifestações religiosas, sendo possível especular sobre a

Debates do NER, Porto Alegre, Ano I6, N. 27, P. 233-258, JAN./Jun. 2015 
dilatação e o deslocamento das fronteiras dos campos religioso e político, assim como a desregulação institucional e a ressignificação de suas práticas (Hervieu-Léger, 2008; Burity, 2001; 2008).

Nesse contexto, buscando analisar as dinâmicas que envolvem os campos político e religioso, o presente artigo problematiza as representações de jovens quanto às esferas da religião e da política e das relações entre ambas, tomando como mote as eleições proporcionais ocorridas em 2012 no município de Campo Mourão, Paraná. As discussões em pauta fundamentam-se na perspectiva de complexidade e interdisciplinaridade (Morin, 1991; 2002; Alvarenga et al., 2011; Vasconcelos, 2007), compreendendo a importância da articulação entre as diversas áreas de conhecimento para a abordagem e investigação do tema proposto. Em vista das dinâmicas e formas de organização da sociedade contemporânea, destacamos a importância de integrar, à perspectiva científica, as incertezas, contradições, ambiguidades e multidimensionalidade dos fenômenos, em especial para o estudo da constituição das identidades, das lógicas de poder e dinâmicas sociais que permeiam a problemática aqui apresentada.

Para a pesquisa cujos dados são aqui apresentados, foram realizadas entrevistas semiestruturadas com vinte e quatro jovens (18 a 25 anos) de instituiçôes religiosas evangélicas, a saber: Igreja Assembleia de Deus (AD), Igreja do Evangelho Quadrangular (IEQ), Igreja Presbiteriana Renovada (IPR) e Igreja Universal do Reino de Deus (IURD). A escolha por tais instituições religiosas, às quais se vinculavam os jovens participantes, deu-se em função do apoio concedido a candidatos que concorreram ao legislativo municipal de Campo Mourão, no pleito eleitoral de $2012^{5}$. As entrevistas foram realizadas no período que antecedeu as eleições municipais, tematizando questôes relacionadas ao cotidiano e às aspirações do jovem (trabalho, estudos, família, projeto de futuro); suas percepçôes quanto ao

5 O desempenho eleitoral, as estratégias de campanha e as representações político-religiosas invocadas pelos candidatos vinculados às instituições religiosas foram analisados e publicados em Mezzomo, Pátaro e Bonini (2014), e Mezzomo, Pátaro e Onofre (2014).

Debates do NER, Porto Alegre, ano i6, N. 27, P. 233-258, JAn./Jun. 2015 
apoio concedido pela instituição religiosa ao candidato; seu entendimento acerca das aproximaçōes entre os campos da religião e da política, bem como sua compreensão sobre o momento eleitoral.

Nas eleições municipais de 2012, Campo Mourão contava com 64.967 eleitores (TRE/PR, 2013) e uma população de mais de 90 mil habitantes. No tocante aos dados referentes à religião, tem-se uma maioria de católicos (60.513), enquanto que os evangélicos somam um total de 20.720 (IBGE/ Cidades, 2014). A Tabela 1 traz as informaçôes referentes à presença demográfica de católicos e evangélicos, em especial da Assembleia de Deus (AD), Igreja do Evangelho Quadrangular (IEQ), Igreja Presbiteriana (IP) ${ }^{6}$ e Igreja Universal do Reino de Deus (IURD), no município de Campo Mourão e também no Paraná.

Tabela 1 - Distribuição da população no estado do Paraná e no município de Campo Mourão nas religiōes Católica e Evangélica (AD, IEQ, IP e IURD)

\begin{tabular}{|c|c|c|c|c|}
\hline \multirow{2}{*}{ Religiāo } & \multicolumn{2}{|c|}{ Estado do Paraná } & \multicolumn{2}{|c|}{ Campo Mourão } \\
\hline & Quantidade & $\%$ & Quantidade & $\%$ \\
\hline Católica & 7.268 .935 & 69,6 & 60.513 & 69,4 \\
\hline Evangélica & 2.316 .213 & 22,2 & 20.720 & 23,8 \\
\hline Assembleia de Deus & 467.274 & 4,5 & 3.289 & 3,8 \\
\hline $\begin{array}{l}\text { Igreja do Evangelho } \\
\text { Quadrangular }\end{array}$ & 195.069 & 1,9 & 2.171 & 2,5 \\
\hline Igreja Presbiteriana & 97.952 & 0,9 & 2.766 & 3,2 \\
\hline $\begin{array}{c}\text { Igreja Universal do Reino } \\
\text { de Deus }\end{array}$ & 75.638 & 0,7 & 465 & 0,5 \\
\hline Total da população & 10.444 .526 & 100,0 & 87.194 & 100,0 \\
\hline
\end{tabular}

Fonte: IBGE - Cidades, 2014; IBGE - Estados, 2014.

6 O Censo do IBGE apresenta os dados da Igreja Presbiteriana, não detalhando suas especificações institucionais.

Debates do NER, Porto Alegre, ANo I6, N. 27, P. 233-258, JAN./Jun. 2015 
Ao relacionar as temáticas da juventude, da religião e da política, parte-se de uma abordagem interdisciplinar, a fim de compreender de que forma os elementos religiosos, utilizados como estratégia de campanha política nas eleições proporcionais do município de Campo Mourão/PR em 2012, são significados pelos jovens vinculados a instituições religiosas que manifestam apoio a determinados candidatos durante a campanha eleitoral. A pesquisa se dá não no sentido de indicar se tais relações entre religião e política são ou não corretas ou desejáveis, mas de analisar de que forma os jovens compreendem a articulação entre os campos da religião e da política.

A construção de uma investigação interdisciplinar fundamentada na perspectiva de complexidade pressupõe não apenas uma abertura para o risco e para as incertezas, como também uma postura investigativa autônoma que, para além do movimento de disjunção, redução e abstração dos fenômenos, busca contextualizar, englobar, com base nas concepções de auto-organização e religação que devem balizar o olhar para a problemática investigada (Morin, 1991; Rodrigues, 2006; Vasconcelos, 2007; Santos, 2010). Nesse movimento, fazem-se pertinentes o trânsito e diálogo entre as diferentes disciplinas, em busca de conceitos e metodologias que possibilitem evidenciar a complexidade do real.

$\mathrm{Na}$ sequência, discutiremos os resultados obtidos buscando analisar a compreensão dos jovens participantes em vista de colaborar com a problematização das fronteiras entre religião e política na contemporaneidade.

\section{JOVENS VINCULADOS A INSTITUIÇÕES RELIGIOSAS}

Foram entrevistados seis jovens de cada uma das instituições religiosas consideradas, a saber: AD, IEQ, IPR e IURD. A Tabela 2 apresenta informações referentes ao perfil dos participantes, por instituição religiosa. 
Tabela 2 - Perfil dos jovens entrevistados

\begin{tabular}{|c|c|c|c|c|}
\hline Sexo & Idade & Estudos & Trabalho e auxílio na renda familiar & Pessoas com quem mora \\
\hline \multicolumn{5}{|c|}{ Igreja Assembleia de Deus (AD) } \\
\hline Fem. & 18 anos & Cursando Ensino Superior & Trabalha, auxiliando na renda familiar & Pai, mãe e irmãos \\
\hline Fem. & 18 anos & Cursando Ensino Médio & Não está trabalhando & Pai, mãe e irmãos \\
\hline Fem. & 20 anos & Cursando Ensino Superior & Trabalha, auxiliando na renda familiar & Pai, mãe, irmãos e avô \\
\hline Masc. & 18 anos & Não está estudando & Trabalha, não auxilia na renda familiar & Mãe e padrasto \\
\hline Masc. & 20 anos & Cursando Ensino Superior & Não está trabalhando & Pai e mãe \\
\hline Masc. & 22 anos & Cursando Ensino Superior & Trabalha, não auxilia na renda familiar & Pai, mãe e irmãos \\
\hline \multicolumn{5}{|c|}{ Igreja do Evangelho Quadrangular (IEQ) } \\
\hline Fem. & 20 anos & Não está estudando & Trabalha, não auxilia na renda familiar & Pai e mãe \\
\hline Fem. & 22 anos & Cursando Ensino Superior & Trabalha, não auxilia na renda familiar & Pai e mãe \\
\hline Fem. & 23 anos & Não está estudando & Trabalha, auxiliando na renda familiar & Pai, mãe e irmãos \\
\hline Masc. & 20 anos & Cursando Ensino Superior & Trabalha, não auxilia na renda familiar & Irmão \\
\hline Masc. & 23 anos & Não está estudando & Trabalha, não auxilia na renda familiar & Sozinho \\
\hline Masc. & 23 anos & Não está estudando & Trabalha, auxiliando na renda familiar & Pai e mãe \\
\hline
\end{tabular}




\begin{tabular}{|c|c|c|c|c|}
\hline \multicolumn{5}{|c|}{ Igreja Presbiteriana Renovada (IPR) } \\
\hline Fem. & 21 anos & Não está estudando & Trabalha, auxiliando na renda familiar & Pai, mãe e irmãos \\
\hline Fem. & 22 anos & Cursando Ensino Superior & Trabalha, auxiliando na renda familiar & Pai, mãe e irmão \\
\hline Fem. & 25 anos & Cursando Ensino Superior & Trabalha, não auxilia na renda familiar & Pai, mãe e irmãos \\
\hline Masc. & 19 anos & $\begin{array}{c}\text { Cursando EJA - Educação para } \\
\text { Jovens e Adultos }\end{array}$ & Trabalha, não auxilia na renda familiar & Mãe, padrasto e irmã \\
\hline Masc. & 21 anos & Não está estudando & Trabalha, auxiliando na renda familiar & Pai, mãe e irmão \\
\hline Masc. & 22 anos & Cursando Ensino Superior & Trabalha, auxiliando na renda familiar & Pai e mãe \\
\hline \multicolumn{5}{|c|}{ Igreja Universal do Reino de Deus (IURD) } \\
\hline Fem. & 18 anos & Cursando Ensino Superior & Trabalha, auxiliando na renda familiar & Pai e mãe \\
\hline Fem. & 18 anos & Não está estudando & Trabalha, auxiliando na renda familiar & Pai, mãe e tio \\
\hline Fem. & 24 anos & Não está estudando & Trabalha, auxiliando na renda familiar & Pai e mãe \\
\hline Masc. & 18 anos & Não está estudando & Não está trabalhando & Mãe e padrasto \\
\hline Masc. & 19 anos & $\begin{array}{c}\text { Não está estudando (frequenta } \\
\text { curso profissionalizante) }\end{array}$ & Não está trabalhando & Pai \\
\hline Masc. & 22 anos & Não está estudando & Trabalha, auxiliando na renda familiar & Mãe e avó \\
\hline
\end{tabular}

Fonte: Dados da pesquisa 
Podemos verificar que, dos vinte e quatro jovens, dez $(41,7 \%)$ estão cursando o Ensino Superior e doze (50\%) declararam não estar frequentando a educação formal. Chama atenção a quantidade significativa de jovens afastados do meio escolar ou universitário, considerando, sobretudo, que a faixa etária ideal para o Ensino Superior compreende a idade de 18 a 24 anos.

Em particular, a IEQ e a IURD são as instituições religiosas que apresentam os índices mais expressivos, contando com quatro e cinco jovens, respectivamente, que declararam não estar estudando. Esses dados contrastam com o perfil dos jovens da $\mathrm{AD}$, cuja vinculação ao Ensino Superior compreende quatro participantes, sendo que um declarou cursar o Ensino Médio e apenas um não está estudando.

No que se refere ao perfil socioeconômico, apenas quatro (16,7\%) dos vinte e quatro jovens declararam não estar trabalhando (sendo dois da IURD e dois da AD), a maioria mora com os pais e somente um jovem, pertencente à IEQ, afirmou estar morando sozinho.

Durante a entrevista realizada, os jovens foram levados a refletir acerca de valores e aspectos significativos em seu cotidiano, sua identidade e suas aspiraçôes, devendo destacar os três elementos mais importantes de sua vida. Nesse momento, houve poucas diferenças entre os jovens das instituiçōes religiosas, sendo que vinte e dois $(91,7 \%)$ dos vinte e quatro participantes destacam Deus em primeiro lugar. A família foi indicada como o elemento de maior relevância para dois jovens, sendo mencionada como a segunda opção para outros vinte e um participantes. Amigos, estudos, trabalho e futuro foram apontados como terceiro elemento mais importante. A respeito desta questão, vale salientar que apenas um jovem fez menção a Jesus (IURD), e a Igreja foi citada por dois jovens (AD e IURD).

Com base no perfil indicado, podemos inferir acerca da importância que Deus e a família - com a qual, inclusive, a grande maioria ainda convive - exercem na constituição das identidades dos participantes, tendo em vista a expressiva recorrência a tais elementos.

Debates do NER, Porto Alegre, ANo I6, N. 27, P. 233-258, JAN./Jun. 2015 
Tabela 3 - Vínculo com a instituição religiosa

\begin{tabular}{|c|c|c|c|c|c|}
\hline \multirow{2}{*}{ Sexo } & \multirow{2}{*}{ Idade } & \multirow{2}{*}{$\begin{array}{c}\text { Tempo de } \\
\text { vinculação à religiaao }\end{array}$} & \multirow{2}{*}{ Mesma religião dos pais? } & \multicolumn{2}{|c|}{ Vinculação ou contato com outras religióes? } \\
\hline & & & & $\mathrm{S} / \mathrm{N}$ & Circunstância \\
\hline \multicolumn{6}{|c|}{ Igreja Assembleia de Deus (AD) } \\
\hline Fem. & 18 anos & Desde que nasceu & Sim & Sim & Tem contato com a IEQ. \\
\hline Fem. & 18 anos & Desde que nasceu & Sim & Não & - \\
\hline Fem. & 20 anos & Há 3 anos & $\begin{array}{l}\text { Sim (pai e mãe eram } \\
\text { vinculados à IPR) }\end{array}$ & Sim & $\begin{array}{c}\text { IPR até os } 17 \text { anos. Já teve contato } \\
\text { com outras igrejas evangélicas. }\end{array}$ \\
\hline Masc. & 18 anos & Desde que nasceu & Sim & Não & - \\
\hline Masc. & 20 anos & Desde que nasceu & Sim & Não & - \\
\hline Masc. & 22 anos & Desde que nasceu & Sim & Não & - \\
\hline \multicolumn{6}{|c|}{ Igreja do Evangelho Quadrangular (IEQ) } \\
\hline Fem. & 20 anos & Desde que nasceu & Sim & Não & - \\
\hline Fem. & 22 anos & Há 19 anos & $\operatorname{Sim}$ & Sim & Já frequentou a Igreja Católica. \\
\hline Fem. & 23 anos & Desde que nasceu & Sim & Sim & Já frequentou outra igreja evangélica. \\
\hline Masc. & 20 anos & Há 1,5 ano & $\begin{array}{c}\text { Sim, da mãe } \\
\text { (pai não frequenta religião) }\end{array}$ & Não & - \\
\hline Masc. & 23 anos & Há 4 anos & $\begin{array}{c}\text { Não (pai católico e mãe } \\
\text { Testemunha de Jeová) }\end{array}$ & Sim & Já teve contato com várias igrejas. \\
\hline Masc. & 23 anos & Há 3 anos & Sim & Não & - \\
\hline
\end{tabular}




\begin{tabular}{|c|c|c|c|c|c|}
\hline \multicolumn{6}{|c|}{ Igreja Presbiteriana Renovada (IPR) } \\
\hline Fem. & 21 anos & Desde que nasceu & Sim & Não & - \\
\hline Fem. & 22 anos & Desde que nasceu & $\operatorname{Sim}$ & Sim & Tem contato com outras religiôes \\
\hline Fem. & 25 anos & Desde que nasceu & Sim & Não & - \\
\hline Masc. & 19 anos & Há 8 anos & $\begin{array}{c}\text { Sim, da mãe } \\
\text { (pai não frequenta religião) }\end{array}$ & Não & - \\
\hline Masc. & 21 anos & Desde que nasceu & Sim, da mãe (pai católico) & Não & - \\
\hline Masc. & 22 anos & Desde que nasceu & Sim & Sim & $\begin{array}{c}\text { Tem contato com outras } \\
\text { religiōes evangélicas. }\end{array}$ \\
\hline \multicolumn{6}{|c|}{ Igreja Universal do Reino de Deus (IURD) } \\
\hline Fem. & 18 anos & Há 7 anos & $\begin{array}{c}\text { Não (pai católico e mãe não } \\
\text { frequenta religião) }\end{array}$ & Sim & $\begin{array}{c}\text { Já frequentou a Igreja Católica } \\
\text { e outras religiōes evangélicas. }\end{array}$ \\
\hline Fem. & 18 anos & Há 14 anos & $\begin{array}{c}\text { Sim, da mãe (pai é evangélico } \\
\text { mas não frequenta) }\end{array}$ & Não & - \\
\hline Fem. & 24 anos & Há 8 anos & Sim & Sim & Já frequentou a IPR. \\
\hline Masc. & 18 anos & Desde que nasceu & Sim & Sim & $\begin{array}{c}\text { Frequentou a Igreja Católica } \\
\text { por algum tempo. }\end{array}$ \\
\hline Masc. & 19 anos & Há 16 anos & Sim & Sim & Tem contato com outras religiōes \\
\hline Masc. & 22 anos & Há 1 ano & $\begin{array}{l}\text { Sim, da mãe } \\
\text { (pai não frequenta religião) }\end{array}$ & Sim & Já frequentou a Igreja Católica. \\
\hline
\end{tabular}


No que se refere ao pertencimento religioso dos participantes entrevistados, alguns elementos merecem destaque. Em primeiro lugar, a maioria dos jovens vinculados à $\mathrm{AD}$ e à IPR (totalizando dez dos doze entrevistados) declara pertencer à instituição religiosa desde o nascimento. Em contraposição, na IURD e IEQ, isso ocorre em apenas um e dois casos, respectivamente.

Ao analisarmos a religião dos familiares, podemos verificar que a maioria dos jovens frequenta a mesma instituição religiosa dos pais, havendo apenas dois casos (IURD e IEQ) em que a afiliação religiosa do participante não corresponde à de nenhum de seus genitores. Essa correspondência e sintonia no pertencimento religioso de pais e filhos talvez estejam relacionadas ao fato de os jovens ainda morarem com seus familiares, conforme já apontado anteriormente, sugerindo uma vez mais a influência exercida pela família na constituição das identidades desses sujeitos.

Ainda quanto aos participantes, verificamos que doze (50\%) afirmam ter tido algum tipo de contato com outras religióes, com destaque especial para as demais evangélicas e também à religião católica. Outro elemento que sugere o trânsito religioso se refere à experiência de cinco jovens que, tendo nascido na religião à qual se vinculam atualmente, declaram frequentar ou ter frequentado outras igrejas. Por fim, ainda sobre este aspecto, os entrevistados pertencentes à IURD acenam para certa desinstitucionalização do sagrado, tendo em vista que apenas um deles declara nunca ter tido contato com outras religióes.

Na sequência, discutiremos os resultados em três eixos de análise: significados atribuídos pelo jovem à religião; significados atribuídos à política; e a compreensão acerca das relações entre religião e política.

\section{SIGNIFICADOS ATRIBUÍDOS À RELIGIÃO}

Conforme já apresentado anteriormente, Deus foi indicado pela maioria dos entrevistados (vinte e dois ou 91,7\%) como sendo a coisa mais importante em suas vidas, seguido pela família e pelos amigos. Os participantes afirmam também que o vínculo com a religião possibilita uma aproximação

Debates do NER, Porto Alegre, Ano I6, N. 27, P. 233-258, JAN./Jun. 2015 
com a salvação, atribuindo à Igreja um papel de importância que reflete e auxilia o jovem em sua maneira de viver, guiando-o ao caminho correto.

Fernandes (2007) evidencia que em um país como o Brasil, marcado pela expressão religiosa em suas variadas vertentes, a religião configura-se como uma influente variável na compreensão de aspectos sociais e na análise do comportamento juvenil. A religião, dessa forma, exerce influências na maneira de agir e no modo como o sujeito vê o mundo. Indicamos, a seguir, algumas passagens das entrevistas em que tais aspectos são destacados:

Eu tenho que seguir o que a minha igreja tem em seu estatuto, por respeito, mas o que é mais importante pra mim é Deus. (Masc., 23 anos, IEQ).

Olha, a importância é que na palavra de Deus, ele ensina muito a gente o que e como a gente tem que fazer para viver bem, então isso para mim é importante porque cada vez mais a gente aprende mais. (Fem., 18 anos, IURD).

Eu acho que religião é uma das coisas principais na minha vida porque eu acho que sem Deus, sem religião, eu não sei o que eu seria. (Fem., 18 anos, IURD).

Quando questionados sobre o que esperam da religião, os jovens indicaram, em sua maioria, que não esperam da religião ou da igreja em si, mas de Deus, atribuindo valor secundário à denominação da igreja em favor da religiosidade, conforme apontam os seguintes trechos:

Eu creio que religião, ela não leva ninguém a lugar nenhum. Acho que Deus leva as pessoas. Religião, pra mim, é o mal do mundo, porque é ela que separa as pessoas, ela que faz as pessoas brigarem e discutirem. Deus unifica a pessoa. (Masc., 19 anos, IURD).

Da religião eu não espero muito né, mas realmente eu espero em Deus, espero bênçãos na minha vida, ter uma vida boa, como tenho tido desde que eu encontrei a Deus. (Masc., 23 anos, IEQ).

Da religião, nada. [...] tipo assim, meu pensamento não é religião, o meu pensamento é servir, é ter comunhão com Deus, acreditar em Deus. (Fem., 20 anos, $\mathrm{AD})$.

Debates do NER, Porto Alegre, Ano I6, N. 27, P. 233-258, JAN./Jun. 2015 
Da religião eu não espero muita coisa não, porque tem coisa errada [...] da religiāo eu não espero muito, eu espero de Deus, eu confio nele, eu sei que ele me ouve, eu espero dele, da religião não muito. (Masc., 22 anos, IPR).

Os participantes que seguem o raciocínio indicado pelas respostas acima citadas representam quinze dos vinte e quatro entrevistados. A partir deste dado, podemos concordar com a discussão de Fernandes quando aponta que:

Passa-se a falar em busca de religiosidade, mais do que em busca de uma Igreja [...] por fim, a estabelecer formas de vinculação institucional mais autônomas e geridas de acordo com demandas que se distanciam das orientaçōes formais ou oficiais das Igrejas e denominaçōes religiosas. (Fernandes, 2007, p. 161).

A autora indica ainda que esse quadro não se apresenta como uma crise para os fiéis, porque estes continuam a considerar a religião importante, mas há um menor exclusivismo religioso, indo contra as formas tradicionais e atendendo às demandas contemporâneas dos jovens fiéis que consideram que "[...] há algo de verdadeiro em todas as religiôes" (Fernandes, 2007, p. 161).

Nesse sentido, concordamos com Alves (2004), ao constatar que, ao contrário do que se pensa, de que a juventude perdeu as crenças, abandonou as práticas religiosas e afogou-se no individualismo, no niilismo e no consumismo, é possível afirmar que a religiosidade ainda é perceptível e, atualmente, passa por transformaçóes. Em sua pesquisa com jovens universitários, verifica "[...] uma intensa religiosidade, em conflito com um sagrado civilizado e sistematizado pela instituição, habitando um estágio originário no qual a emoção predomina sobre a razão" (Alves, 2004, p. 81). Por esse motivo, o autor compreende a necessidade e importância de atentarmos para aquilo que subsiste de religiosidade para além da religião institucionalizada, seja ela explicitamente enquadrada pelos dogmas tradicionais ou espontânea, "[...] mais ou menos artesanal, mais ou menos selvagem, ou até mesmo inconsciente de suas amarras religiosas" (Ferry; Gauchet, 2008, p. 43).

Debates do NER, Porto Alegre, ano I6, N. 27, P. 233-258, JAn./Jun. 2015 
Ao comentarem acerca de seu projeto de futuro, todos os entrevistados afirmam que pretendem continuar vinculados à religião, servindo e pautando suas escolhas em Deus. Esse dado evidencia uma influência da religiosidade na constituição das identidades desses sujeitos. Em pesquisa realizada junto a jovens, Perez, Oliveira e Assis (2004) identificam igualmente que a religião se apresenta como um valor central, ao lado da família e do trabalho, estando à frente do valor atribuído à escola e aos amigos. De forma análoga, Fernandes (2011) verifica que a religião tem sido valorizada pelos jovens, ainda que haja indícios de novos modelos de pertencimento e vínculo religioso, de modo que não é possível apontar para um indiferentismo religioso por parte da juventude - mesmo para aqueles que se denominam sem-religião (Novaes, 2004).

Ademais, compreendemos que, diante da fragilização das estruturas sociais, políticas e culturais brasileiras, resultantes de ausências no campo da educação formal, da empregabilidade no mercado de trabalho e da confiança no universo político, a religião pode servir como instituições geradoras de significados e de sentido a projetos individuais e coletivos (Sofiati, 2011).

Nesse contexto, Ferry e Gauchet (2008) discutem que as morais laicas não conseguem se encarregar do conjunto de experiências e angústias vividas pelos indivíduos no contexto contemporâneo. Para estes filósofos, o discurso moral laico, tal como as sociedades o compreendem, não responde a todas as indagaçôes, de modo que questôes relativas ao próprio sujeito, à conduta de sua existência, à orientação de sua experiência, entre outros, acabam ficando de fora. Assim, as religiōes têm ainda trazido respostas, bem como fornecido suporte e segurança aos sujeitos.

\section{SIGNIFICADOS ATRIBUÍDOS À POLÍTICA}

O segundo eixo de análise investigado refere-se aos significados atribuídos pelos jovens à política, considerando inclusive o momento da campanha para as eleições municipais. Os jovens evidenciaram aspectos negativos e descrença quanto à política atual, ao mesmo tempo em que indicavam expectativas de

Debates do NER, Porto Alegre, ANo I6, N. 27, P. 233-258, JAN./Jun. 2015 
mudanças para o futuro. Muitos dos jovens demonstraram certa indiferença quanto aos assuntos relacionados à política, tanto pela falta de compreensão quanto pela aversão ao tema, enquanto outros evidenciavam a importância do político como representante do povo, responsável pela criação de políticas públicas para melhoria da vida da população, entre outros. De acordo com Müxel (1997), a evocação da palavra "política" suscita, antes de qualquer outra perspectiva, imagens negativas:

A rejeição da política, como se pode ver diariamente, é vivamente expressa, os desvios dos homens e das instituições são denunciados com a mesma força de convicção, tanto pelos estudantes como pelos assalariados, pelos jovens sejam eles diplomados ou não; de direita; de esquerda ou sem orientação política definida. A homogeneidade dos argumentos é impressionante. A constatação é unânime. A crise de representação política se impõe pelo seu caráter evidente. (Müxel, 1997, p. 153).

Dentre os entrevistados, foi recorrente a manifestação de descrença quanto à atitude individualista e corrupta dos políticos da atualidade, cuja escolha é também responsabilidade da população. A este respeito, os participantes ressaltam a corrupção que tem marcado o cenário brasileiro, caracterizando a classe política como desonesta, estando seus interesses pessoais acima do dever de representar a população. Alguns jovens destacam a responsabilidade do povo em relação à política atual, porque, ao incorporar o pensamento de que "todos os políticos são ladrōes", o eleitor deixa de refletir sobre o seu voto, e acaba compartilhando do entendimento de que basta votar naquele que irá "roubar menos". Nesse sentido, para esses jovens, a falta da consciência política conduziria à eleição de representantes corruptos, como fica evidenciado no trecho a seguir:

Então esses políticos usam essas fraquezas dessas pessoas para ganhá-las e se elegerem, e daí você fica reclamando que sua vida está uma desgraça, porque aquele político é ladrão. Não é o político que é ladrão, é ela mesma que está errada, porque ela colocou uma pessoa inadequada, ela deixou ser comprada. (Masc., 22 anos, IURD).

Debates do NER, Porto Alegre, ano i6, N. 27, P. 233-258, JAn./Jun. 2015 
No trecho em destaque, o jovem aponta a responsabilidade do eleitor, que muitas vezes aceita trocar seu voto por bens materiais ou favores, não refletindo acerca das consequências de tal atitude, que acaba por eleger alguém que posteriormente irá usar seu cargo em benefício próprio.

Se é recorrente um ceticismo em relação ao cenário atual, os participantes expressam, ao mesmo tempo, expectativas positivas com relação à política. Assim, manifestam a esperança de que os políticos desempenhem idoneamente sua função, preocupando-se mais com as necessidades da população do que com seus próprios interesses, e destacam a importância do momento eleitoral para a escolha das "pessoas certas" a ocuparem os cargos públicos. Em relação à política local, anseiam por melhorias em setores como educação, saúde e infraestrutura. Os trechos a seguir apresentam as expectativas dos jovens participantes com relação à política:

O que todo mundo espera, que seja uma coisa melhor, que existam pessoas lá no poder que possam mudar o que é atualmente, que possam ter mais benefícios para a população, tanto na saúde, educação e tantas outras coisas, que algum dia isso possa mudar. (Fem., 21 anos, IPR).

Olha, eu espero que agora, a primeira vez que eu vou votar, que o meu voto seja certo, numa pessoa certa, e que mude de verdade, porque até agora a gente não viu diferença na política. Então agora eu espero ver as coisas acontecerem. (Fem., 18 anos, IURD).

A gente quer ver uma política ativa, que represente de fato as pessoas, que não se envolva só em corrupção. Eu tenho esperança ainda, se bem que pouca, mas que possa ter esse vínculo de representação fiel ao povo, aos eleitores. (Masc., 20 anos, $\mathrm{AD}$ ).

Eu espero que cada dia melhore mais, sabe. Menos corrupção, que eles façam boas leis, que administrem melhor a cidade, administrem melhor tudo, até o Brasil. Que eles diminuíssem essa corrupção, acho que a principal coisa que tinha que acontecer, que eles tão visando muito dinheiro, só querem aumentar a renda deles. Eles não estão pensando na população, e a saúde está um horror, cada dia pior, as cidades também. (Fem., 20 anos, IEQ). 
Apesar da esperança em possíveis mudanças na política, apenas seis jovens indicaram ver uma relação com o seu futuro, demonstrando uma compreensão de que as melhorias na cidade, na educação e saúde serão importantes para o desenvolvimento de seus projetos pessoais e de suas famílias. Vejamos algumas respostas:

Sim, eu vejo, porque se os impostos forem bem investidos e tiver saúde, eu vou ter uma boa saúde, [...] meus filhos vão ter uma educação, minha família, meus netos vão ter uma boa educação. Eu não vejo pra mim, mas para os meus netos, para os meus filhos. (Masc., 19 anos, IPR).

Acho que vai ter relação sim. Vai ter relação porque eu posso [...] ter importância pra ajudar as pessoas a entender como é importante a escolha delas. Eu tenho certeza que pode ser que meu futuro envolva isso aí também. (Masc., 22 anos, AD).

A gente sempre vai depender da política. Não depender totalmente, mas se eu abrir meu escritório, eu vou depender do comércio em si, dependo do prefeito, de ele estar investindo ali, eu acho que política sempre tem relação. (Fem., 22 anos, IPR).

Os demais jovens indicaram que não veem relação entre a política e seus projetos para o futuro. Esse dado contrasta com o questionamento sobre a relação entre religião e o futuro, que foi indicado por todos como importante, como base para toda vida. De certa forma, essa constatação reforça a ideia, já destacada, da descrença para com a esfera da política formal, que estaria associada a aspectos negativos. A este respeito, a literatura vem indicando um distanciamento por parte dos jovens do que se compreende tradicionalmente pela participação política, especialmente daquela atrelada à institucionalidade do Estado. Por outro lado, cabe problematizar se não haveria, na atualidade, outras estratégias de participação e engajamento político dos jovens, além de novas pautas políticas, relacionadas tanto a questóes universais (consciência planetária) quanto ao cotidiano da juventude, tais como o mundo do trabalho, o lazer, a ação solidária, a violência, como já tem sido apontado por algumas pesquisas, sobretudo a partir da década de 1990 (Müxel, 1997; Fernandes, 2007; Boghossian; Minayo, 2009).

Debates do NER, Porto Alegre, Ano I6, N. 27, P. 233-258, JAn./Jun. 2015 


\section{RELAÇÕES ENTRE RELIGIÃO E POLÍTICA}

Não se pode mais ignorar a visibilidade pública das religiōes na cena contemporânea, seja na seara da política, da cultura ou do cotidiano, nas quais os atores religiosos movimentam-se e trazem a público sua linguagem, seu ethos e suas demandas (Burity, 2008). A cada nova eleição no país, é notória a crescente presença de candidatos a cargos eletivos, majoritários ou proporcionais, que reivindicam e afirmam a sua condição de agentes ou líderes religiosos, e que expõem abertamente os seus vínculos com a religião por ocasião da campanha eleitoral. Com tal estratégia, muitas vezes, o candidato busca angariar apoios e legitimar sua candidatura com base em representações religiosas que o qualificariam como o mais preparado para o exercício do mandato público (Burity, 2011; Oro, 2001; Machado, 2006; Camurça, 2008). O que se percebe, também, é o movimento crescente e organizado das instituições religiosas em direção ao campo da política, indicando e apoiando determinados candidatos, a fim de pautar suas demandas e ocupar o espaço público.

Em vista de tais consideraçôes, procurou-se analisar a compreensão dos jovens acerca de tais aproximações entre religião e política. Em específico, no pleito eleitoral de 2012, em Campo Mourão, a AD, IEQ, IPR e IURD - instituições religiosas às quais se vinculavam os jovens entrevistados - mantiveram uma postura proativa no sentido de apoiar determinados candidatos ao legislativo municipal.

Para parte dos vinte e quatro jovens entrevistados, a política deve ser permeada pelo sagrado, de modo que o candidato religioso, por seu caráter, deve atuar como um representante de Deus na esfera pública. Assim, uma vez que a religião está em todos os lugares, deve se fazer presente também na política, por meio da atuação efetiva do agente religioso ${ }^{7}$. Com esse

7 Entende-se por agente religioso o candidato que estabelece abertamente um vínculo ativo com uma religião, ou é líder ou mesmo representante de alguma instituição religiosa (Oro, 2001, p. 10).

Debates do NER, Porto Alegre, Ano I6, N. 27, P. 233-258, JAN./Jun. 2015 
entendimento, os jovens parecem atribuir ao exercício do mandato de tais candidatos uma missão sacralizadora do meio político. Tal compreensão não parece isolada, tendo em vista a investigação de Miranda (2006). Para esta autora, a política, embora inevitável - por ser obrigatória - não é vista como parte do cotidiano dos fiéis, uma vez que é associada ao roubo e à corrupção. Diante de tal cenário, a “[...] maneira de fazê-la 'menos ruim' é 'torná-la religiosa'. [...] Jesus é a salvação também na política, e nela sua ação é mediada pelos candidatos que representam as denominaçóes" (Miranda, 2006, p. 155). Vejamos nas palavras dos próprios jovens:

Muitos que, acredito, têm a cabeça mais fechada acham que religião e política não se misturam. Mas até na bíblia é citado que se as pessoas, os servos de Deus, não forem governados por pessoas de Deus, perecerão. Então acredito que uma pessoa que comanda as outras pessoas tem que ter o temor de Deus no coração. (Masc., 23 anos, IEQ).

O homem diz que a política não é de Deus, muita gente fala. Eu creio que a política é de Deus, até porque o homem que salvou Jesus, que tirou Jesus da cruz depois de ele ter sido morto, foi José de Arimatéia, que era um político, quer dizer, a política é de Deus. (Masc., 19 anos, IURD).

Agora, como entrou na época da política, a gente está tentando eleger um vereador da igreja. Tem muitos homens lá na Câmara que só vão por dinheiro, mas a gente quer uma pessoa de Deus lá, que esteja por coisa séria. Então, pra mim, não tinha relação nenhuma [entre religião e política] e agora tem, porque agora eu me aprofundei e aprendi que precisa sim, que uma pessoa religiosa [na Câmara] vai fazer bem. (Fem., 18 anos, IURD).

Ainda a respeito do papel do agente religioso na política, Maia (2006, p. 107) ressalta a busca pela sacralização do espaço político, no qual imperam atitudes de realização de prazeres individuais. Nesta guerra santa, determinadas instituições evangélicas propõem-se a limpar toda e qualquer impureza que está presente na esfera da política. A postura dos jovens participantes da pesquisa parece endossar tal compreensão, na medida em que todos os entrevistados concordam com a posição da igreja na indicação de seus candidatos.

Debates do NER, Porto Alegre, ano I6, N. 27, P. 233-258, JAn./Jun. 2015 
Outro elemento que merece destaque é a manifestação de nove jovens $(37,5 \%)$ ao defender que, mais do que uma indicação de um candidato ligado à sua igreja, sua eleição garantiria a defesa dos interesses particulares da instituição religiosa, que muitas vezes é desassistida e vitimada pela gestão pública. Vejamos:

É importante que a gente tenha um representante da igreja dentro da prefeitura, porque às vezes podem surgir leis que possam prejudicar, restringir a nossa forma de adorar a Deus. (Fem., 20 anos, AD).

A gente sempre vê aqui os políticos que se levantam contra a igreja, principalmente a Igreja Universal, tentando prejudicar, tentando fechar de alguma forma, $[. .$.$] por isso que a gente tem nosso candidato, pra defender, defender$ a obra. [...] eu sou a favor por causa disso, porque precisa ter alguém lá pra defender, pra ir contra. (Fem., 24 anos, IURD).

Eu pensei que política e religião deveriam ser opostas e nunca deveriam se encontrar. Mas hoje eu penso diferente, hoje eu digo que nós precisamos ter os nossos representantes, porque como nós representamos o evangelho de Cristo no mundo, muitas coisas estão saindo desse evangelho. Nós precisamos de representantes pra defender esse evangelho, então se nós deixarmos, escolhermos aleatoriamente os nossos representantes, com certeza nós seremos cada vez mais suprimidos. Mas se nós escolhermos, buscarmos nossos representantes de acordo com a nossa forma de vida, eu acho que pode ajudar muito. Então eu acho que deve haver ligação [entre política e religião] sim. (Masc., 22 anos, $\mathrm{AD}$ ).

De certa forma, a compreensão desses jovens vinculados às instituições religiosas denota a dilatação e permeabilização das fronteiras entre os campos político e religioso - ou seja, uma aproximação entre o que Mircea Eliade (1992) denomina o mundo do profano e do sagrado.

Não obstante o consentimento acerca da indicação dos candidatos pela Igreja, bem como o posicionamento favorável quanto às aproximações entre religião e política, devemos considerar que alguns dos jovens entrevistados expressaram ressalvas e preocupações acerca das articulações entre os campos

Debates do NER, Porto Alegre, ANo I6, N. 27, P. 233-258, JAN./Jun. 2015 
político e religioso. A corrupção na esfera política, o desempenho insatisfatório e/ou imoral de um candidato eleito pela Igreja, o uso oportunista da vinculação religiosa na campanha e mesmo a defesa da laicidade do estado são alguns dos argumentos apresentados pelos jovens que justificariam o necessário afastamento, tendo em vista as especificidades próprias do mundo da religião e da política.

\section{CONSIDERAÇÕES FINAIS}

A experiência obtida com a pesquisa e os resultados alcançados possibilitam esboçar alguns elementos acerca da compreensão dos jovens de Campo Mourão, vinculados a instituições religiosas, no que se refere às temáticas da religião, da política e suas inter-relações, a partir de suas vivências subjetivas e sociais, bem como diante do momento das eleições municipais de 2012.

A religião e a política têm se apresentado para esses jovens como próximas a seu cotidiano, embora com intensidade e significados variados. Em geral, enquanto a religião apresenta-se como um caminho para manter o jovem ligado a Deus, a política é encarada com certo ceticismo, diante do cenário atual, marcado por notícias que denotam a imoralidade, corrupção e a defesa de interesses corporativistas de seus gestores. Ao refletirem acerca das relaçóes entre política e religião, há um ditame de significaçóes positivas e negativas, encaradas por uns como uma chance de salvação para a política contemporânea - uma vez que representantes de Deus fariam a diferença, sendo honestos e defendendo a igreja no legislativo -, e por outros como dois campos distantes demais para se articularem.

Acerca do estatuto do fenômeno religioso na inter-relação com o mundo contemporâneo, Ferry e Gauchet (2008) compreendem a existência de dois processos simultâneos, quais sejam: a saída da religião - compreendida como saída da capacidade do religioso estruturar a política e a sociedade -, e a permanência do religioso na ordem da convicção última dos indivíduos, observando nesse terreno um amplo espectro de variações, segundo as experiências históricas e nacionais.

Debates do NER, Porto Alegre, ano I6, N. 27, P. 233-258, JAn./Jun. 2015 
Assim, diante de tais considerações, bem como da já mencionada dilatação e ressignificação das fronteiras entre os campos da religião e da política, cabe indagar acerca do processo de constituição das identidades no contexto contemporâneo. Tal tema vem sendo abordado por diferentes autores, os quais chamam a atenção para um entendimento que supere a compreensão dicotomizada e essencializada do conceito, ressaltando o caráter dinâmico, multidimensional e relacional da constituição dos sujeitos na interface com as instituições, as culturas e a sociedade (Hall, 1999; Bauman, 2005; Maffesoli, 1996; Castells, 2013; Morin, 2002).

Destacamos, desse modo, a importância de novas pesquisas que venham a problematizar a constituição das identidades juvenis na interface entre a religião e a política, buscando compreender alguns dos elementos imbricados neste processo, bem como as dinâmicas de ressignificação, acionamento e ocultamento de sentidos, valores e crenças dos sujeitos jovens nas trajetórias e processos sociais articulados à religião e à política. Por fim, as compreensões epistemológicas aqui apresentadas levam-nos a entender, com base em Fernandes (2007), que as articulações entre juventude, religião e política não formam uma síntese, nem mesmo se sobrepõem, e que as interconexões desses campos são permeadas por processos de ressignificação e reordenamento diante das representaçôes construídas pelos sujeitos. 


\section{REFERENNCIAS}

ALVARENGA, Augusta Thereza de et al. Histórico, fundamentos filosóficos e teórico-metodológicos da interdisciplinaridade. In: PHILIPPI JR., Arlindo; SILVA NETO, Antônio J. (Org.). Interdisciplinaridade em ciência, tecnologia \& inovação. Barueri: Manole, 2011. p. 3-68.

ALVES, Vicente Paulo. Fenomenologia da religião: pesquisas sobre a experiência religiosa com universitários e suas implicações para o ensino religioso. In: HOLANDA, Adriano. Psicologia, religiosidade e fenomenologia. Campinas: Editora Alínea, 2004. p. 79-93.

BAUMAN, Zygmunt. Identidade. Rio de Janeiro: Jorge Zahar Editor, 2005.

BOGHOSSIAN, Cyntia; MINAYO, Maria Cecília. Revisão sistemática sobre juventude e participação nos últimos 10 anos. Revista Saúde e Sociedade, São Paulo, v. 18, n. 3, p. 411-423, 2009.

BURITY, Joanildo. Religião e política na fronteira: desinstitucionalização e deslocamento numa relação historicamente polêmica. Revista de Estudos de Religião, São Paulo, n. 4, p. 27-45, 2001.

Religião, política e cultura. Revista Tempo Social, São Paulo, v. 20, n. 2, p. 83-113, 2008.

Fé na revolução: Protestantismo e o discurso revolucionário brasileiro (1961-1964). Rio de Janeiro: Novos Diálogos, 2011.

CAMURÇA, Marcelo Ayres. Ciências Sociais e Ciências da Religiāo: polêmicas e interlocuções. São Paulo: Paulinas, 2008.

CASTELLS, Manuel. O poder da identidade. 8. ed. São Paulo: Paz e Terra, 2013.

ELIADE, Mircea. O sagrado e o profano. São Paulo: Martins Fontes, 1992.

Debates do NER, Porto Alegre, ano I6, N. 27, P. 233-258, JAn./Jun. 2015 
FERNANDES, Ślvia Regina. Adesão religiosa no segmento juvenil: apolitização ou reinvenção da política? Seropédica, Rio de Janeiro, v. 29, n. 2, p. 152-165, jul./dez. 2007.

- Marcos definidores da condição juvenil para católicos e pentecostais da Baixada Fluminense: algumas proposições a partir de um survey. Revista Religião e Sociedade, Rio de Janeiro, v. 31, p. 96-125, 2011.

FERRY, Lucy; GAUCHET, Marcel. Depois da Religião: o que será do homem depois que a religião deixar de ditar a lei? Rio de Janeiro: DIFEL, 2008.

HALL, Stuart. A identidade cultural na pós-modernidade. Rio de Janeiro: DP\&A, 1999.

HERVIEU-LÉGER, Danièle. O Peregrino e o convertido: a religião em movimento. Petrópolis: Vozes, 2008.

INSTITUTO BRASILEIRO DE GEOGRAFIA E ESTATÍSTICA (IBGE). Cidades. Disponível em: <http://cidades.ibge.gov.br>. Acesso em: 7 abr. 2014. . Estados. Disponível em: <http://www.ibge.gov.br/estadosat/>. Acesso em: 7 abr. 2014.

MACHADO, Maria das Dores. Política e religiāo: a participação dos evangélicos nas eleições. Rio de Janeiro: FGV, 2006.

MAFFESOLI, Michel. No fundo das aparências. Rio de Janeiro: Vozes, 1996.

MAIA, Eduardo Lopes Cabral. Os evangélicos e a política. Revista Em Tese, Florianópolis, v. 2, n. 2 (4), p. 91-112, ago./dez. 2006.

MEZZOMO; Frank Antonio; PÁTARO, Cristina Satiê de Oliveira; BONINI, Lara Grigoleto. Religião e política nas eleições ao Legislativo municipal de Campo Mourão. Debates do NER, Porto Alegre, v. 1, n. 25, p. 271-289, jan./jun. 2014. 
MEZZOMO; Frank Antonio; PÁTARO, Cristina Satiê de Oliveira; ONOFRE, Lucas. Evangélicos na política: as eleições proporcionais de Campo Mourão em 2012. REVER: Revista de Estudos da Religião, São Paulo, v. 14, n. 2, jul./dez. 2014.

MIRANDA, Júlia. O candidato da igreja: do que nos fala a sua presença na política brasileira. In: LEMENHE, Maria Auxiliadora; CARVALHO, Rejane Vasconcelos Accioly (Org.). Politica, cultura e processos eleitorais. Fortaleza: Fundação Konrad Adenauer, 2006.

MORIN, Edgar. O Método 5: a humanidade da humanidade. Porto Alegre: Sulina, 2002.

Introdução ao pensamento complexo. Lisboa: Instituto Piaget, 1991.

MÜXEL, Anne. Jovens dos anos noventa: à procura de uma política sem "rótulos". Revista Brasileira de Educação, Rio de Janeiro, n. 5 e 6, p. 151-166, maio/dez. 1997.

NOVAES, Regina. Os jovens "sem religião": ventos secularizantes, "espírito de época” e novos sincretismos: notas preliminares. Revista Estudos Avançados, São Paulo, v. 18, n. 52, p. 321-330, 2004.

Juventude, religião e espaço público: exemplos "bons para pensar" tempos e sinais. Religião e Sociedade, Rio de Janeiro, v. 31, n. 1, p. 184-208, 2012.

ORO, Ari Pedro. Religião e política nas eleições 2000 em Porto Alegre (RS). Debates do NER, Porto Alegre, ano 2, n. 3, 2001.

PEREZ, Léa Freitas; OLIVEIRA, Luciana; ASSIS, Marcos. Religião, valores morais e política entre a juventude mineira do Pólo Capital: observaçōes preliminares. Numem: Revista de Estudos e Pesquisa da Religião, Juiz de Fora, v. 7, n. 1, p. 47-61, 2004.

Debates do NER, Porto Alegre, Ano I6, N. 27, P. 233-258, JAN./Jun. 2015 
RODRIGUES, Maria Lucia. Metodologia multidimensional em Ciências Humanas: um ensaio a partir do pensamento de Edgar Morin. In: RODRIGUES, Maria Lucia; LIMENA, Maria Margarida (Org.). Metodologias multidimensionais em Ciências Humanas. v. 14. Brasília: Líber Livro, 2006. p. 13-32.

SANTOS, Boaventura de Sousa. Um discurso sobre as ciências. 7. ed. São Paulo: Cortez, 2010.

SOFIATTI, Flávio Munhoz. Religiāo e juventude: os carismáticos. São Paulo: Idéias \& Letras, 2011.

TRIBUNAL REGIONAL ELEITORAL DO PARANÁ - TRE/PR. Zonas eleitorais. Disponível em: <http://www.tre-pr.jus.br/institucional/zonas -eleitorais/zonas-eleitorais-tre-pr-pesquisa-por-municipio-1>. Acesso em: 10 set. 2013.

VASCONCELOS, Eduardo Mourão. Complexidade e pesquisa interdisciplinar: epistemologia e metodologia operativa. 3. ed. Petrópolis: Vozes, 2007.

Recebido em: 30/10/2014

Aprovado em: 25/11/2014 